\title{
The role of the laboratory in the diagnosis process in a patient with mildly elevated hCG: a case report
}

\section{[Hafif yüksek hCG'li hastada tanı alma sürecinde laboratuvarın rolü: Olgu sunumu]}

https://doi.org/10.1515/tjb-2020-0106

Received March 2, 2020; accepted July 14, 2020; published online September 15, 2020

\begin{abstract}
Objetives: In this case report, the role of the laboratory in the diagnosis process of the patient was treated with methotrexate (Mtx) who was diagnosed with ectopic pregnancy by endometrial biopsy as a result of the exclusion of the possibility of phantom HCG following the patient with $\beta H C G$ values was discussed.

Case presentation: Our 25-year-old female patient admitted to our hospital obstetrics and gynecology outpatient clinic with irregular menstruation was evaluated with a pre-diagnosis of pregnancy. The hCG level was examined and ultrasonographically evaluated by the clinician. In the initial evaluation of the 25 -year-old patient, the HCG concentration of $47 \mathrm{mIU} / \mathrm{mL}$ was determined.

Conclusion: Laboratory specialists should be aware of potential problems in hCG measurement. Clinicians and laboratory specialists should always be on consultation to solve clinical problems.
\end{abstract}

Keywords: phantom HCG; ectopic pregnancy; consultation; false positive HCG.

*Corresponding author: Medine Alpdemir, Balıkesir State Hospital, Clinical Biochemistry, Balıkesir, Turkey, E-mail: bitigic@hotmail.com. https://orcid.org/0000-0003-2625-0246

Mehmet Fatih Alpdemir, Clinical Biochemistry, Balıkesir State Hospital, Balıkesir, Turkey, e-mail: mfalpdemir@gmail.com. https:// orcid.org/0000-0003-3015-1478

ilknur Toka, Obstetrics and Gynecology Clinic, Balıkesir Devlet Hastanesi, Balıkesir, Turkey
Özet

Amaç: $\mathrm{Bu}$ olgu sunumunda $\beta \mathrm{HCG}$ değerleri ile takip edilen hastanın fantom HCG olasılığının dışlanması sonucunda, endometrial biyopsi ile ektopik gebelik tanısı konulan metotreksatla $(\mathrm{mtx})$ tedavi edilen hastanın tanı alma sürecinde laboratuvarın rolü tartışılmıştır.

Olgu sunumu: Hastanemiz kadın doğum ve hastalıkları polikliniğimiz düzensiz menstruasyon şikayeti ile başvuran 25 yaşında kadın hastamız gebelik ön tanısı ile değerlendirildi. hCG düzeyi bakıldı ve ultrasonografi olarak klinisyen tarafından değerlendirildi. 25 yaşındaki hastanın ilk değerlendirmesinde bakılan $\beta$ HCG konsantrasyonu $47 \mathrm{mIU} / \mathrm{mL}$ olarak saptand.

Sonuç: Laboratuvar uzmanları $\beta$ HCG ölçümündeki potansiyel problemleri farkında olmalıdır. Klinisyenler ve labotuvar uzmanları tanısal problemleri çözmek için her zaman konsültasyonda bulunmalıdır.

Anahtar kelimler: Fantom HCG; ektopik gebelik; konsültasyon; yalancı pozitif HCG.

\section{Introduction}

Human chorionic gonadotropin (hCG) is a glycoprotein hormone produced by syncytiotrophoblast cells of the placenta. Its biologically active form, intact hCG, consists of two subunits. hCG measurements are used to diagnosis and monitoring of pregnancy, pregnancy-related disorders, or trophoblastic and some non-trophoblastic tumors. The hCG concentration in the blood is high in some nonpregnancy conditions such as gestational trophoblastic disease, non-gestational malignancies, hCG from the pituitary gland, and phantom hCG. In addition, the presence 
of human anti-mouse IgG or heterophilic antibodies results in false-positive hCG elevation. Therefore, it is necessary to determine the reason for the presence of resistant high hCG in women who are not pregnant [1].

Consultation is a general approach to solving clinical problems. Consultation between clinical and laboratory specialists is important to determining diagnosis and treatment accurately and quickly. Medical laboratory specialists should therefore collaborate with clinical doctors concerning test selection and interpretation of results [2].

In this report, we present a case that emphasizes the role of a laboratory in faster progression to diagnosis in a non-pregnancy case with high hCG, as a result of consultation between the clinician and a laboratory specialist. In addition, we also examine steps a laboratory can take to reduce hCG false positives.

\section{Case report}

\section{Medical history of the patient}

A 25-year-old woman admitted to our obstetrics and gynecology outpatient clinic with irregular menstruation complaints was evaluated with a pre-diagnosis of pregnancy. Her last menstrual period had started 36 days before. She wasn't taking medications, and her medical history was unremarkable. There were not gynecological malignancies in her family medical story. Our patient had no abdominal pain or metrorrhagia. Routine biochemistry, whole blood and hCG tests were requested. In the transvaginal ultrasonographic examination by the obstetrician, intrauterine pregnancy and extrauterine pregnancy finding were not found, and no ovarian or pelvic mass was observed. The patient's endometrial thickness was determined as $6.7 \mathrm{~mm}$. There is no consensus regarding the minimum endometrial thickness required for a successful pregnancy; however, a minimum endometrial thickness of 6 or $7 \mathrm{~mm}$ is often considered acceptable for successful implantation [3].

In the first assessment of the patient, the hCG result was measured as $47 \mathrm{mIU} / \mathrm{mL}$. Other blood results are shown in Table 1 . After this result, hCG was measured again $48 \mathrm{~h}$ later. The second hCG concentration was found to be $47.2 \mathrm{mIU} /$ $\mathrm{mL}$. In the third hCG follow-up, it was measured as $48.8 \mathrm{mIU} / \mathrm{mL}$. As a result of the clinician's examination of the patient and consultation with laboratory specialists, phantom hCG or heterophile antibody interference was considered. To rule out phantom hCG, the the patient's sample was measured by dilute serum $\mathrm{hCG}(1 / 2,1 / 4$, and $1 / 8$ ). In the second step, hCG was measured via immunoassay and card test methods in the patient's urine sample.
Urine hCG level was determined as $22 \mathrm{mIU} / \mathrm{mL}$ via immunoassay, and the card test qualitative hCG was positive. hCG was tested for heterophile antibody positivity by two other commercial methods, described below. Finally, the sample was treated with a heterophilic antibody blocking tube. The results obtained from these different methods, and after use of the heterophilic antibody blocking tube, were quite similar (Table 2). As a result of these evaluations, the clinician was informed that phantom hCG could be ruled out. Figure 1 presents an algorithm outlining an approach for detecting false-positive hCG results. In this case, the possibility of a false positive was excluded as a result of consultation between clinician and laboratory specialist.

The physician aspirated the endometrium for the separation of an abnormal intra-over located pregnancy or ectopic pregnancy. The pathological examination of the curettage material, the patient had neither pregnancy tissue nor findings indicating an endometrial disorder. The patient's hCG level was checked a day after curettage, and had not changed (normally, hCG decreases after curettage, with a half-life of 24-36 h). As a result of this, the physician administered $70 \mathrm{mg}$ (weight-adjusted) of Methotrexate (Mtx). Four days later, hCG had decreased to $25.5 \mathrm{mIU} / \mathrm{mL}$, and by the seventh day to $11 \mathrm{mIU} / \mathrm{mL}$. The patient was discharged. A final measurement made one-week postdischarge found that hCG had decreased to $<0.1 \mathrm{mIU} / \mathrm{mL}$.

In sum, hCG false positivity was excluded via the laboratory's examinations, the patient avoided unnecessary hCG follow-ups, and treatment was initiated quickly. If our patient had had phantom hCG or heterophilic antibody positivity, and the clinician had not consulted on the results with the laboratory, the patient could have undergone unnecessary surgery and chemotherapy treatment.

\section{Laboratory analyses}

The first serum hCG measurement and post-treatment follow-up hCG were measured with an immunoassay hCG reagent on the Architect i2000 device (Abbott Diagnostic).

Table 1: Serial changes in Serum hCG concentration in the case.

\begin{tabular}{lrl}
\hline Time, day & hCG $\mathbf{~ I U} / \mathbf{m L}$ & Intervention \\
\hline 0 (first visit) & 47.5 & None \\
2 & 47.1 & None \\
4 & 48.1 & Curettage \\
5 & 47.5 & Mtx, A day after curettage \\
9 & 25.5 & 4th day after mtx \\
11 & 11.8 & 7th day after mtx \\
18 & $<0.1$ & None. Final hCG concentration \\
\hline
\end{tabular}


Table 2: The results and methods to exclusion of Phantom hCG or heterophile antibody.

\begin{tabular}{lr}
\hline Process & hCG, $\mathbf{m I U} / \mathbf{m L}$ \\
\hline Urine hCG card test & Positive \\
Urine hCG (immunoassay) & 22 \\
Roche & 45.2 \\
Siemens & 49.2 \\
hCG dilution & 48.2 \\
$1 / 2$ & $23,0.2$ \\
$1 / 4$ & 13.5 \\
$1 / 8$ & 5.2 \\
After heterophile antibody tube & 45.2 \\
\hline
\end{tabular}

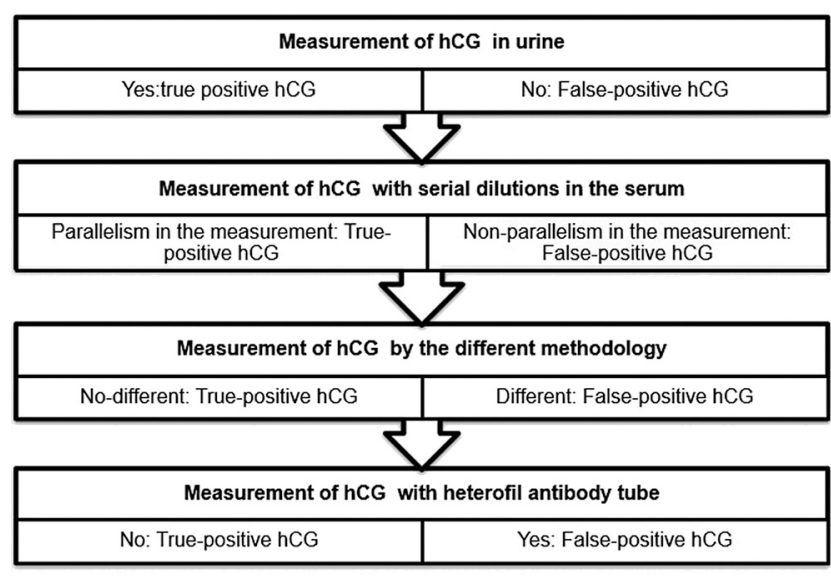

Figure 1: Algorithm outlines an approach for the detection of falsepositive hCG results.

Elecsys 2010 (Roche Diagnostics, Germany) and Immulite 2000 (Siemens Healthcare, Germany) instruments and immunoassay reagents belonging to these analyzers were used to measure hCG with other commercial methods. Qualitative measurements were performed with hCG card test (Laboquick, hCG test, Koroglu group, Turkey). The Laboquick pregnancy test has $20 \mathrm{mIU} / \mathrm{mL}$ hCG sensitivity and offers $96-100 \%$ sensitivity, $98-100 \%$ specificity, and $>99 \%$ accuracy. A heterophilic antibody blocking tube (Scantibodies laboratory, USA) was used to determine the presence of heterophilic antibody interference.

\section{Discussion}

Laboratory tests are the most important tool used in patient diagnosis and treatment. Many clinical laboratory specialists need to do more advanced laboratory research to interpret the results obtained and assist in diagnosis and treatment. Additional tests or research that clarify the diagnosis of the patient will speed treatment and prevent unnecessary testing (imaging or laboratory) or invasive intervention, thus saving both time and money in the process. In this case, false-positive hCG status was excluded by advanced laboratory examinations as a result of consultation with the clinician. Otherwise, as seen in the case report of Durmuş et al., as a result of falsepositive hCG elevation, the patient may be exposed to unnecessary treatment such as chemotherapy or surgery [4]. In similar case report, the patient received unnecessary Mtx therapy [5].

hCG measurements are credible diagnostic tests for pregnancy assessment, but an understanding of their limitations is essential for correctly interpreting their results. Laboratory measurement of hCG in the urine is the first step in cases of resistant hCG elevation, such as early pregnancy (normal and ectopic), that are not supported by the patient's clinic or determined by imaging. In such cases, active-form intact hCG is detected in the urine. Laboratory experts can quickly exclude or identify phantom hCG with a qualitative hCG test in urine. This is readily available in most laboratories, but if unavailable can easily be individually sourced from all pharmacies. The second stage can be repeated by serial dilution. In addition, to rule out phantom hCG, it is important to exclude dilutional parallelism (1/2-1/5) and the presence of heterophilic antibodies in the laboratory's hCG results. In the presence of human antibodies against heterophilic antibodies and animal antibodies, the results do not show a proportional change as expected. Another method to detect the presence of heterophilic antibodies is tubes that block these antibodies. However, this method is relatively costly and not always available in laboratories. It can be repeated with different commercial methods to exclude false positives that will occur depending on the method used $[6,7]$.

The false-positive phantom hCG and phantom choriocarcinoma syndrome (pseudohypergonadotropinemia) points to constant mild rises of hCG. Patients with these falsepositive results have been diagnosed with gestational trophoblastic disease and undergone a variety of diagnostic procedures, chemotherapy, hysterectomy, and other surgical procedures [8]. There are a great of number causes of falsepositive hCG measurements [9], as abstracted in Table 3. Improbable findings or persistence of low hCG concentrations are not an unusual condition. Outside of pregnancy, persistent low levels of hCG may be associated with various benign and malignant situations, e.g. quiescent gestational trophoblastic disease, increased pituitary hCG-like peptides, or false positive elevation caused by circulating heterophile antibodies [7]. 
Table 3: Reason of false-positive hCG assay results.

Pituitary hCG-like peptides.

Free hCG-subunit production.

Previous injection of hCG.

Interference with non-hCG glycoproteins like hLH or hLH-beta subunit.

Familial hCG syndrome.

Anti-animal antibodies:

- Species specific (e.g., HAMA), heterophilic antibodies

- IgA deficiency

- Rheumatoid factor

- Anti-hCG antibodies nonspecific serum factors

Assay issues:

- Assay contaminants

- Radioactive iodine fluorophores

The presence of false-positive hCG due to phantom hCG and heterophile antibody is clinically well documented. Although it is a well-known occurrence, these case reports show that heterophilic antibody interference and phantom hCG were not considered as possibilities until weeks after the unnecessary surgical and medical treatment. At this stage, the importance of laboratory consultation becomes apparent. The most important methodological task for ruling out phantom hCG or heterophilic antibodies falls to clinical laboratories. In our case report, the presence of false positive hCG at the beginning of the treatment was excluded, and advanced treatment protocols were started for the patient. Today, effective use of an increasing variety of laboratory tests in diagnosis and treatment has increased consultation between the laboratory and the clinic. This application [2], which began in the USA in 1960, is also included in the scope of rational laboratory practices under the Ministry of Health in our country, and this practice has been requested nationwide [10].

\section{Conclusions}

Clinicians and laboratory specialists should collaborate to evaluate laboratory results more efficiently and to achieve definitive results in diagnostic and treatment applications. This cooperation will enable faster, more effective treatment. Additionally, hCG measurements are credible diagnostic tests for pregnancy assessment, but a full understanding of their limitations is essential for correct result interpretation.
Results must be confirmed by different methods to exclude false-positive hCG elevation.

Research funding: None declared.

Author contribution: All the authors have accepted responsibility for the entire content of this submitted manuscript and approved submission.

Competing interests: The authors declare no conflicts of interest regarding this article.

Informed consent: Informed consent was obtained from all individuals included in this study.

Ethical approval: The present investigation was conducted in accordance with the Declaration of Helsinki for human studies.

\section{References}

1. Stenman UH, Alfhan H. Determination of human chorionic onadotropin. Best Pract Res Clin Endocrinol Metabol 2013;27: 783-93.

2. Burke MD. Clinical laboratory consultation: appropriateness to laboratory medicine. Clin Chim Acta 2003 Jul 15;333:125-9.

3. Singh N, Bahadur A, Mittal S, Malhotra N, Bhatt A. Predictive value of endometrial thickness, pattern and sub-endometrial blood flows on the day of hCG by 2D Doppler in in-vitro fertilization cycles: a prospective clinical study from a tertiary care unit. J Hum Reprod Sci 2011;4:29-33.

4. Durmuş AB, Gürsoy Yarcı A, Kiseli M, Çağlar GS. Phantom hCG ve adnexial MAS management. Turk J Reprod Med Surg 2017;1:120-2.

5. González Aguilera B, Syrios P, Gadisseur R, Luyckx F, Cavalier E, Beckers A, et al.. Persistent low levels of serum hCG due to heterophilic mouse antibodies: an unrecognized pitfall in the diagnosis of trophoblastic disease. Gynecol Endocrinol 2016;32: 439-41.

6. ACOG Committee on Gynecologic Practice. Avoiding inappropriate clinical decisions based on false-positive human chorionic gonadotropin test results. Int J Gynaecol Obstet 2003; 80:231-3.

7. Braunstein GD. False-positive serum human chorionic gonadotropin results: causes, characteristics, and recognition. Am J Obstet Gynecol 2002;187:217-24.

8. Cole LA. Phantom hCG and phantom choriocarcinoma. Gynecol Oncol 1998;71:325-9.

9. Greene DN, Grenache DG. Education Committee of the Academy of Clinical Laboratory Physicians and Scientist. Pathology consultation on human chorionic gonadotropin testing for pregnancy assessment. Am J Clin Pathol 2015;144:830-6.

10. Available from: https://tetkikteshis.saglik.gov.tr/TR,32919/ akilci-laboratuvar-kullanimi-projesi.html [Accessed 5 Jan 2020]. 